\title{
Nutrient addition increases consumption rates of tropical algae with different initial palatabilities
}

\author{
Alvin Y. Chan", Katie Lubarsky, Kaitlin N. Judy, Peggy Fong \\ Department of Ecology and Evolutionary Biology, University of California, 621 Young Drive South, Los Angeles, \\ California 90095-1606, USA
}

\begin{abstract}
While nutrient enrichment increases herbivory rates on highly palatable species of tropical algae, it is unclear how nutrient enrichment affects species with differing initial palatabilities. We determined that there was a wide range in relative palatability among 5 perennial and common species of Caribbean coral reef algae in a cafeteria-style choice experiment, with overall preference for Acanthophora spicifera the highest, Dictyota dichotoma and Caulerpa sertularioides intermediate, and Turbinaria turbinata and Sargassum polyceratium the lowest, although there were significant differences in grazing rates among algal species between the 2 fringing reef sites tested. We then tested the hypothesis that increased nutrient content in algae increases palatability using choice experiments between enriched and ambient algal samples for each of 3 species along this palatability gradient: A. spicifera, D. dichotoma, and S. polyceratium. For all species, herbivores selected enriched over ambient samples across the 2 sites despite contrasting herbivore guilds (i.e. dominated by sea urchin Diadema antillarum versus herbivorous fishes). However, despite increased palatability of enriched $S$. polyceratium, overall herbivory on this species was still relatively low compared to other studies, suggesting that $S$. polyceratium in this system may have stronger chemical defenses, or that a specialist herbivore guild may be missing on this Caribbean reef. Regardless of the mechanism, our study implies that anthropogenic or natural events that result in high supplies of nutrients in coral reef seawater will increase overall seaweed palatability, even of unpalatable species.
\end{abstract}

KEY WORDS: Tropical marine algae - Dictyota dichotoma ' Sargassum polyceratium . Acanthophora spicifera $\cdot$ Herbivory $\cdot$ Nutrient enrichment

\section{INTRODUCTION}

Consumption plays a strong role in mediating communities of primary producers in marine ecosystems (e.g. Hillebrand et al. 2007, Burkepile \& Hay 2008, 2009), with effects on community structure that may be temporally or spatially variable (see Lefevre \& Bellwood 2011). Coral reefs are particularly affected by top-down control, as herbivory mediates between coral or macroalgal dominance. For example, some seaweeds may reduce the abundance of corals by poisoning them if the seaweeds are not controlled by herbivores (Rasher \& Hay 2010). Indeed, some re- search has indicated that lowered herbivory and impaired herbivore populations may result in a phase shift from coral to algal dominance (e.g. Hughes 1994, Hughes et al. 1985, 2007).

Primary producers have evolved a suite of mechanisms that can reduce their susceptibility to herbivory (i.e. lower their palatability). Evolution has directed the development of antiherbivore defenses in macroalgae, such as structural or chemical defenses (Duffy \& Hay 1990). An example of a macroalga with structural defenses is Ascophyllum nodosum, a temperate macroalga that responds to simulated herbivory by increasing tensile strength and toughness 
in its tissue (Lowell et al. 1991). Chemical defenses can also deter herbivory and make macroalgae less palatable (e.g. Van Alstyne \& Houser 2003). However, on coral reefs with intact herbivore communities, herbivore pressure is very strong and even defended algae are consumed, leaving little or no macroalgae outside of refuges. When herbivore communities are reduced (via overfishing), the first type of algae to proliferate are defended algae, which are beginning to dominate tropical coral reefs (Fong \& Paul 2011).

Factors that influence the production of defenses (e.g. resource availability and herbivory rates) may also cause variation in nutritional quality of coral reef algae, controlling the ability of producers to alter their palatability and reduce their consumption by herbivores (e.g. Erickson et al. 2006). It is argued that when resources are low, primary producers that grow slowly and invest more in antiherbivore defense are favored, and that the opposite is also true (i.e. high resources favor fast-growing producers with few antiherbivore defenses) (Coley et al. 1985). Therefore, resources and defenses interact to optimize primary producer growth. However, high levels of resources influence the effectiveness of antiherbivore defenses. For instance, dictyol, a chemical defense, is more effective deterring certain species of amphipods when placed in low nutritional quality foods than when placed in high quality foods (CruzRivera \& Hay 2003). Though previous studies suggest there is an interaction between nutrients and palatability in coral reef ecosystems (e.g. Sotka \& Hay 2009), this has not been studied extensively.

While it is well established that nutrient addition stimulates herbivory and increases consumption rates on highly palatable tropical macroalgae (i.e. macroalgae that is readily consumed), little is known about the effect on less palatable species. For example, Fong et al. (2006) found that herbivores preferentially consume nutrient enriched tissue of the highly palatable alga Acanthophora spicifera on coral reefs in the eastern Pacific, and Boyer et al. (2004) found the same interaction between nutrients and the susceptibility to herbivory of $A$. spicifera on a Caribbean reef. In contrast, while there is some evidence that nutritional content increases the palatability of chemically defended macroalgae within temperate ecosystems (Van Alstyne et al. 2009), it is unclear how nutrient enrichment affects consumption of less palatable tropical macroalgal species.

Defended macroalgae with varying degrees of palatability are beginning to dominate reef ecosystems globally; thus, investigating the effects of nutrients on herbivory rates on these species may prove crucial in conserving these ecosystems. Our objectives were to: (1) investigate the relative initial palatability of 5 tropical species of macroalgae, and (2) test the effect of nutrient enrichment on the palatability of 3 macroalgae with differing initial palatabilities. To accomplish this, we first conducted a choice assay where natural herbivore guilds were allowed to choose between multiple macroalgal species (i.e. 'cafeteria' style selection). Next, we conducted separate choice experiments comparing consumption on enriched and ambient thalli of 3 species of macroalgae (Acanthophora spicifera, Dictyota dichotoma, Sargassum polyceratium) that had varying levels of initial palatability. We hypothesized that nutrient addition would elevate the concentration of an important nutrient (i.e. nitrogen) in the tissue of our subject species and increase algal palatability across all 3 species.

\section{MATERIALS AND METHODS}

Our study sites were 2 fringing reefs (named cove and point) on the western side of Greater Lameshur Bay, St. John, U. S. Virgin Islands $\left(18^{\circ} 19^{\prime} 8^{\prime \prime} \mathrm{N}, 64^{\circ}\right.$ $\left.43^{\prime} 18^{\prime \prime} \mathrm{W}\right)$, and we conducted all surveys and experiments between 10 and 30 October 2009. Approximately $100 \mathrm{~m}$ separated the sites with an average depth of $\sim 2 \mathrm{~m}$. We quantified the abundance of herbivorous fish and urchins, and size frequency distributions of the dominant herbivorous fishes. Sea urchins Diadema antillarum were counted during the day (09:00 to $15: 00 \mathrm{~h})$ and at dusk as they became active $(17: 00$ to $18: 00 \mathrm{~h})$ in haphazardly placed $1 \mathrm{~m}^{2}$ quadrats within each site. Urchin densities did not differ between day and night ( $t$-test, $\mathrm{n}=40$ [day], $\mathrm{n}=$ 15 [night], $p=0.127$ ), possibly due to the scarcity of cover or lack of predators (see Young \& Bellwood 2011), which allowed us to find all urchins regardless of activity level. Therefore, we pooled the night and day densities and compared the total mean abundances of urchins between sites with a $t$-test. We surveyed herbivorous fish between 10:00 and 14:00 h within 33 haphazardly placed $1 \times 15 \mathrm{~m}$ belt transects in each site, counting acanthurids and scarids, and placing them into size categories of $0-5,>5-10$, and $>10 \mathrm{~cm}$. Although these size categories for fish are much smaller than those used in other studies (e.g. Bonaldo \& Bellwood 2008, Lokrantz et al. 2008), the paucity of fish $>15 \mathrm{~cm}$, likely a result of fishing pressure on this reef, justified this truncated distribution. We used a $t$-test to compare the total number of herbivorous fish between sites, and a Kolmogorov- 
Smirnov test to determine differences in size frequency distributions between sites.

To quantify the relative palatability of the most commonly observed macroalgae, we conducted a cafeteria-style choice experiment at each site. We collected and cleaned epiphytes from 4 species of macroalgae that have a range of chemical defenses as shown in previous research (Dictyota dichotoma: Cetrulo \& Hay 2000, Wiesemeier et al. 2007; Caulerpa sertularioides: Paul \& Fenical 1986, Erickson et al. 2006; Sargassum polyceratium: Boettcher \& Targett 1993, Thabard et al. 2011; Turbinaria turbinata: Meyer et al. 1994, Stiger et al. 2004), and a nonchemically defended species of algae (Acanthophora spicifera: Fong et al. 2006). We weighed $5.0 \pm 0.1 \mathrm{~g}$ (mean $\pm \mathrm{SE}$ ) samples of each alga after drying in a salad spinner for $1 \mathrm{~min}$, and cable-tied a sample of each alga to each experimental unit, which were rocks collected from each site and covered with wire mesh to facilitate attachment. Five replicate experimental units with algae were exposed to herbivores at each site during the day $(8 \mathrm{~h})$ and night $(16 \mathrm{~h})$, separately, to compare diurnal (probably mostly fish) and nocturnal (probably mostly urchin) herbivory rates. We did not deploy controls (for growth) because we were only interested in relative palatability, not absolute, and algae were not subjected to nutrient enrichment. We also did not account for handling losses, which may vary among species but not treatments. The difference between initial and remaining mass of each sample was the total mass eaten, which we used to calculate $12 \mathrm{~h}$ herbivory rates (to account for differences in exposure time between day and night). Because we assumed that the algal samples offered in this choice experiment were not independent, we used a 2-factor MANOVA to compare mean consumption of all algal species between sites and between day and night. Data were transformed (using natural log) to meet assumptions of normality and homoscedasticity.

To assess if herbivores preferred nutrient enriched algae across differing levels of initial palatability, we quantified herbivory rates on enriched and ambient samples of 3 algal species that spanned the range of natural palatability found in our cafeteria-style choice experiments (Acanthophora spicifera, Dictyota dichotoma, Sargassum polyceratium). In separate experiments, each of the 3 algal species were cultured under either nutrient enriched or ambient conditions and exposed to herbivores at both the cove and point. Another complete set of enriched and ambient algal samples was placed in cages to allow for adjustment of herbivory rates due to any differ- ences in growth that may have occurred between sites, species, and enrichment levels. We chose $A$. spicifera because it is palatable (Lewis 1985, Fong et al. 2006), a habitat generalist in shallow areas (Taylor et al. 1986), and stores nutrients (Fong et al. 2006). We chose a moderately palatable species $(D$. dichotoma) and one of the least palatable species (S. polyceratium) from our cafeteria-style experiment. Algae were collected within study sites and cleaned of epiphytes. A sample of each species was split into two $20 \mathrm{l}$ culture containers placed within a continuous flow-through seawater system. Each container was supplied independently with seawater from the bay in an overflow system to ensure they were isolated, and care was taken to maintain the same flow rates through each unit. For each species, 1 container had ambient nutrient levels and the other contained $20 \mathrm{~g}$ Osmocote slow-release fertilizer. Algae were cultured for 3 to $6 \mathrm{~d}$ prior to deployment. To establish the efficacy of nutrient enrichment, 5 samples of algae from each culture were rinsed in freshwater, dried at $<60^{\circ} \mathrm{C}$, ground with a mortar and pestle, and sent to the University of California Davis Isotope Facility to determine nitrogen content. Nitrogen content was significantly elevated in the tissues of all 3 algal species cultured with Osmocote compared to ambient seawater (Table 1).

We cable-tied 1 enriched and 1 ambient sample (5.0 $\pm 0.1 \mathrm{~g})$ to each experimental unit, and paired this with caged (to account for growth) enriched and ambient samples on an adjacent experimental unit ( $<0.5 \mathrm{~m}$ apart). Cages were mesh bags made from nylon window screen sewn with fishing line (Fong et al. 2006). While cages reduced light by $\sim 30 \%$ (Boyer et al. 2004), our experiments were conducted at $2 \mathrm{~m}$ depth where the light levels were quite high; therefore, reduction in growth due to shading was unlikely. After each experiment, we collected, cleaned, spun and re-weighed each algal sample and quantified consumption of algae by subtracting the mass of the open sample from the adjacent caged sample (Boyer

Table 1. Acanthophora spicifera, Dictyota dichotoma, and Sargassum polyceratium. Results of $t$-tests comparing the tissue $\mathrm{N}$ content in ambient and enriched specimens of algae. We present mean values $\pm 1 \mathrm{SE}, \mathrm{n}=5$. Significant $\mathrm{p}$-values shown in bold

\begin{tabular}{|lcccc|}
\hline Species & $\begin{array}{c}\text { Nutrient concentration }(\% \mathrm{~N}) \\
\text { Ambient }\end{array}$ & $\begin{array}{c}\text { Enriched } \\
(1 \text { tail) }\end{array}$ & $\mathrm{p}$ \\
& & & & \\
\hline A. spicifera & $0.83 \pm 0.03$ & $0.93 \pm 0.02$ & 1.86 & $\mathbf{0 . 0 1 0}$ \\
D. dichotoma & $1.37 \pm 0.08$ & $1.68 \pm 0.15$ & 1.87 & $\mathbf{0 . 0 4 9}$ \\
S. polyceratium & $0.79 \pm 0.05$ & $1.02 \pm 0.02$ & 1.86 & $\mathbf{0 . 0 0 2}$ \\
\hline
\end{tabular}


et al. 2004). This method is the same as that used by Stachowicz \& Hay (1996) to correct for changes in mass unrelated to herbivory: $\left[T_{\mathrm{i}} \times\left(C_{\mathrm{f}} / C_{\mathrm{i}}\right)\right]-T_{\mathrm{f}}$, where $T_{\mathrm{f}}$ and $T_{\mathrm{i}}$ are the final and initial mass and $C_{\mathrm{f}}$ and $C_{\mathrm{i}}$ are the final and initial mass of the control. However, because $T_{\mathrm{i}}$ equaled $C_{\mathrm{i}}$ (i.e. $T_{\mathrm{i}}=C_{\mathrm{i}}=5.0 \mathrm{~g}$ ) in our study, the equation mathematically is $C_{\mathrm{f}}-T_{\mathrm{f}}$. Algae were exposed to herbivores for different lengths of time depending on the species. We separated our Acanthophora spicifera study into day and night components because if we had left the samples out for $24 \mathrm{~h}$, there would be no mass left of either treatment to compare. Therefore, we left the day component out for $5 \mathrm{~h}$ and the night component for $12 \mathrm{~h}$, but for comparison we calculated $12 \mathrm{~h}$ grazing rates for both day and night components. Slower herbivory rates allowed us to leave Dictyota dichotoma and Sargassum polyceratium out for $24 \mathrm{~h}$ and $48 \mathrm{~h}$, respectively (without separating into day and night components); however, we calculated $24 \mathrm{~h}$ grazing rates for comparison. We analyzed the results using 2-factor ANOVA to determine site and nutrient effects on mean consumption. No transformations were necessary.

To prevent confounding due to growth, we conducted post-hoc unpaired $t$-tests between caged ambient and enriched samples to test for differences in growth. We reasoned that if there were no differences in growth in the time the samples were left out, growth could not account for differences between ambient and enriched samples. We found no statistical differences between caged ambient and enriched samples for all 3 species (unpaired $t$-tests, all 3 had $p$ $>0.05$ ), showing that there were no significant differences in growth during our experiments.

\section{RESULTS}

Diadema antillarum was more than 4 times more abundant at the cove $\left(3.7 \pm 0.7\right.$ urchins $\left.\mathrm{m}^{-2}\right)$ than the point $\left(0.6 \pm 0.2\right.$ urchins $\mathrm{m}^{-2}$; unpaired $t$-test, $\mathrm{p}=$ $0.0004)$. The point had a higher overall abundance of herbivorous fishes (acanthurids, scarids) $(1.4 \pm 0.3$ fish $\left.15 \mathrm{~m}^{-2}\right)$ compared to the cove $(0.6 \pm 0.2$ fish $15 \mathrm{~m}^{-2}$; unpaired $t$-test, $\left.\mathrm{p}<0.0001\right)$. Size frequency distributions were significantly different between sites (Kolmogorov-Smirnov test, $\mathrm{p}<0.001$ ), with relatively more medium-sized fish at the point and larger fish at the cove; despite this, the large difference in total abundance between the 2 sites resulted in more larger fish at the point in total.

Across all species, there was a difference in mean consumption rate among locations but not between day and night (MANOVA, Table 2). Generally, herbivores preferred Acanthophora spicifera and Caulerpa sertularioides regardless of site or time (Fig. 1). Herbivores at the point (likely herbivorous fishes) consumed amounts of Dictyota dichotoma comparable to the $A$. spicifera and $C$. sertularioides samples (i.e. the most preferred species), while the herbivores at the cove (likely Diadema antillarum) consumed amounts of Dictyota dichotoma comparable to the Sargassum polyceratium and Turbinaria turbinata samples (i.e. the least preferred species).

When testing for nutrient effects, overall, grazing rates on the undefended alga Acanthophora spicifera appeared much higher during the day than at night (Fig. 2). During the day, rapid grazing resulted in no

Table 2. Results of a 2-factor MANOVA on $24 \mathrm{~h}$ herbivory rates for cafeteria-style choice experiment. Significant p-values shown in bold

\begin{tabular}{|lccc|}
\hline Parameter & $F$ (approx. or exact) & df & $\mathrm{p}$ \\
\hline Whole model: Wilks' Lambda & 2.819 & 15 & $\mathbf{0 . 0 0 9}$ \\
Location & 6.192 & 5 & $\mathbf{0 . 0 0 7}$ \\
Day/night & 2.178 & 5 & 0.138 \\
Location $\times$ Day/night & 1.118 & 5 & 0.410 \\
\hline
\end{tabular}
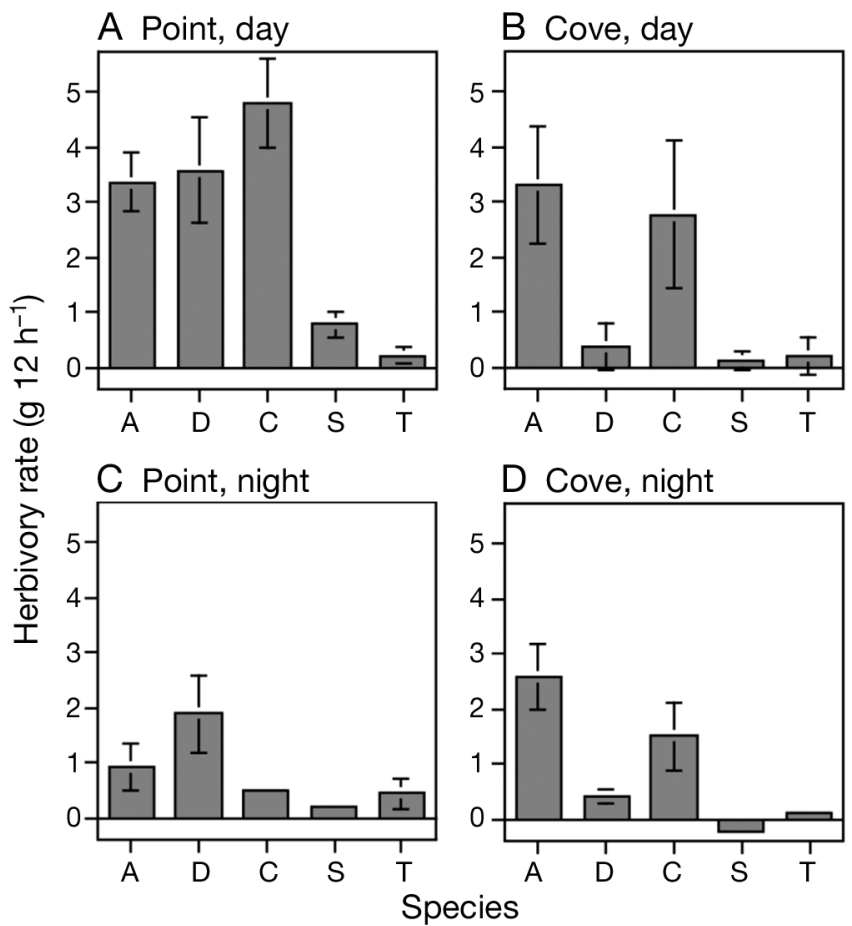

Fig. 1. Algal biomass consumed at the point and cove during the day and at night. $X$-axis shows first letter of the algal genus: Acanthophora spicifera, Dictyota dichotoma, Caulerpa sertularioides, Sargassum polyceratium, Turbinaria turbinata. Mean values $\pm 1 \mathrm{SE}, \mathrm{n}=5$ 

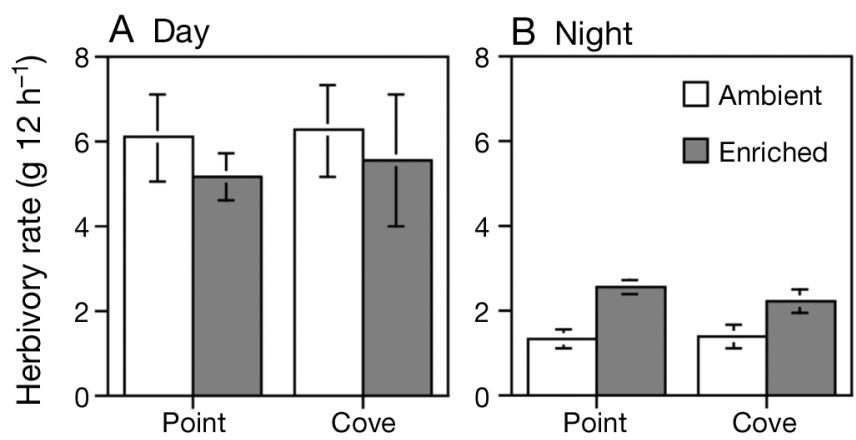

Fig. 2. Acanthophora spicifera. Consumption of enriched and ambient algae measured over $12 \mathrm{~h}$. (A) During the day, and (B) at night. Mean values $\pm 1 \mathrm{SE}, \mathrm{n}=5$

measurable difference in consumption between enriched and ambient algal samples or between sites. However, at night there was significantly higher consumption of enriched over ambient algae, with no difference between sites (Table 3, Fig. 2).

Herbivores demonstrated a strong preference for enriched Dictyota dichotoma (Table 3, Fig. 3). There were no significant effects of site despite differing herbivore guilds between sites. Herbivores also consumed more enriched than ambient Sargassum polyceratium (Table 3, Fig. 3) and there were no effects of site. Differences appeared mainly at the cove, resulting in a nearly significant interaction. However, the total biomass of $S$. polyceratium consumed remained substantially less than that of either Acanthophora spicifera or D. dichotoma, despite enhanced rates due to nutrient enrichment.

\section{DISCUSSION}

Herbivores strongly preferred enriched over ambient algae despite considerable differences in the herbivore community between sites and a broad spectrum of both algal type and palatability. Our surveys showed a clear difference between herbivore communities at each site, demonstrating that both herbivore guilds preferred enriched algae. In addition, herbivores selected enriched samples despite the wide spectrum of algal palatability, as measured for this site by the choice experiment (i.e. high: Acanthophora spicifera; medium: Dictyota dichotoma; low: Sargassum polyceratium). We therefore conclude that herbivores find macroalgae of varying palatabilities more desirable with nutrient addition and that future research should address whether this could be a common characteristic of herbivory dynamics across the Caribbean.

Two of the species we used may have had chemical defenses (Dictyota dichotoma and Sargassum polyc-

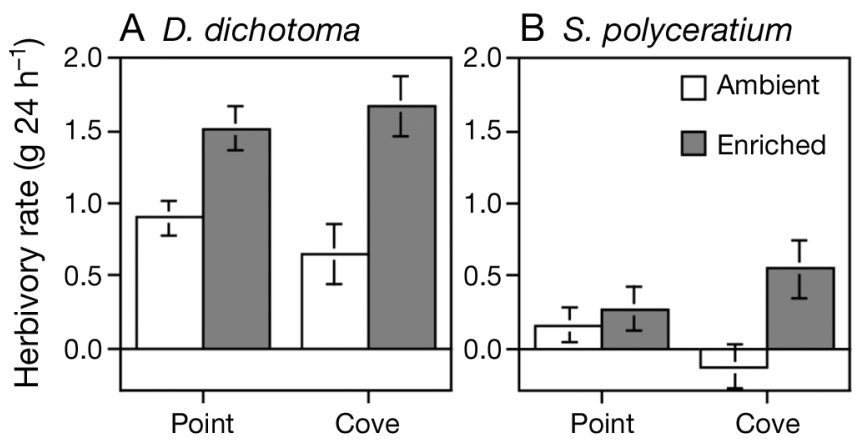

Fig. 3. Dictyota dichotoma and Sargassum polyceratium. Consumption of enriched and ambient (A) D. dichotoma and (B) $S$. polyceratium measured over $24 \mathrm{~h}$. Mean values $\pm 1 \mathrm{SE}$, $\mathrm{n}=5$

Table 3. Acanthophora specifera, Dictyota dichotoma, and Sargassum polyceratium. Results of a 2 -factor ANOVA on $12 \mathrm{~h}$ herbivory rates for the night experiment with $A$. specifera and on $24 \mathrm{~h}$ herbivory rates for $D$. dichotoma and S. polyceratium. Significant p-values shown in bold

\begin{tabular}{|lcccc|}
\hline Species & Parameter & df & $F$ & $\mathrm{p}$ \\
\hline A. specifera & Location & 1 & 0.28 & 0.602 \\
& Nutrient status & 1 & 17.85 & $<\mathbf{0 . 0 0 1}$ \\
& Location $\times$ & 1 & 0.59 & 0.453 \\
& Nutrient status & & & \\
D. dichotoma & Location & 1 & 0.08 & 0.777 \\
& Nutrient status & 1 & 21.12 & $<\mathbf{0 . 0 0 1}$ \\
& Location $\times$ & 1 & 1.34 & 0.264 \\
Nutrient status & & & \\
& Location & 1 & 0.001 & 0.975 \\
& Nutrient status & 1 & 6.34 & $\mathbf{0 . 0 2 3}$ \\
& Location $\times$ & 1 & 3.30 & 0.088 \\
& Nutrient status & & & \\
\hline
\end{tabular}

eratium) and we advance 2, non-mutually exclusive explanations for the apparent decrease in the effectiveness of the chemical defenses: (1) herbivores are more likely to ingest chemical defenses to obtain more nutrients, and (2) nutrients decrease the content of chemical defenses in algal tissue. The rationale for our first hypothesis is that herbivores may be willing to ingest chemical defenses in exchange for more nutrients because algae generally has low nutritional value, which forces herbivores to consume a large amount of algae to obtain nutrients (Fong \& Paul 2011). A laboratory experiment with 1 species of temperate algae and an herbivore came to a similar conclusion (Van Alstyne et al. 2009). The rationale for our second hypothesis is based on a study that showed that younger tissue in Dictyota ciliolate has lower concentrations of chemical defenses than older tissues (Cronin \& Hay 1996). Similarly, added nutrients could cause growth that dilutes defenses in our samples of algae, making them more palatable. Although these 2 hypotheses are not 
mutually exclusive, the increased nutrient concentration of our enriched samples and lack of significant differences in growth of our caged samples regardless of nutrient treatment suggest the first is more likely.

The relative palatability of our algal species confirmed the results of some, but not all, previous studies. Herbivores grazed strongly on Acanthophora spicifera, as expected (Boyer et al. 2004, Fong et al. 2006). Although Caulerpa sertularioides has chemical defenses (Vest et al. 1983), their effectiveness is debated (Lewis 1985). Results from our study support the contention that $C$. sertularioides' defenses are not always effective, because consumption was comparable with A. spicifera, at least at some times and locations. Urchins grazed on Dictyota dichotoma (night grazing) in relatively low to moderate quantities in comparison with other algae, which was consistent with the intermediate palatability found for other Dictyota species (Littler et al. 1983). In contrast, $D$. dichotoma was strongly preferred by herbivorous fishes (daytime grazing), suggesting that on overfished reefs, even with low nutrients and large urchin populations, D. dichotoma could proliferate. Lastly, there is conflicting evidence from the literature showing Sargassum polyceratium and Turbinaria turbinata as both highly palatable (Lewis 1985, Hughes 1994, Hughes et al. 2007, Burkepile \& Hay 2008) and unpalatable (Littler et al. 1983). Our experiments show that $S$. polyceratium and T. turbinata are relatively unpalatable to the herbivore guilds present on this Caribbean reef, as they were consumed the least by our species.

Previous studies found that Sargassum spp. is readily consumed (e.g. Burkepile \& Hay 2008); however, we found that on this heavily fished Caribbean reef, our species of Sargassum was relatively unpalatable to the local herbivore guilds. We suggest this may be due to the lack of a critical functional group or adequate functional sizes within groups. It is argued that different herbivores specialize, effectively creating functional groups (e.g. see Bellwood et al. 2006). One possibility is that $S$. polyceratium is relatively unpalatable to herbivore guilds at our study site because it lacked species that consume $S$. polyceratium. For example, Mantyka \& Bellwood (2007a,b) showed that some siganids readily consume Sargassum sp. In addition, batfish Platax pinnatus on the Great Barrier Reef (Bellwood et al. 2006), as well as other species on Pacific coral reefs (e.g. Hoey \& Bellwood 2010) readily consume Sargassum spp. However, some of these functional groups of fish, such as siganids, do not occur on Caribbean reefs, and some may have been reduced below critical functional thresholds by overfishing. Thus, lack or loss of specialist herbivores may have contributed to the relative unpalatability of $S$. polyceratium in our study. Another possibility is that the lack of large fish on our reefs may have resulted in a loss of functional members within our groups, as some studies have shown that the functional role of herbivorous fish changes with size (e.g. Bonaldo \& Bellwood 2008, Lokrantz et al. 2008). Burkepile \& Hay (2008) found Sargassum spp. to be palatable in Florida, and we suggest this may be due to the presence of larger fish on Florida reefs compared with members of the same groups on our reefs. We hypothesize that the discontinuity of palatability between our study and others may be due to the absence of necessary sizes or functional groups of herbivores.

Our findings support previous studies on palatable species (e.g. Boyer et al. 2004, Fong et al. 2006, Burkepile \& Hay 2009) and extend them to species with a range of palatabilities. The positive relationship between nutrients and palatability will likely become more conspicuous in coral reef ecosystems in the event of natural or anthropogenic increases in nutrient supplies. Though it is argued that nutrient enrichment is not a primary reason behind phase shifts on coral reefs (see Gruner et al. 2008, Burkepile \& Hay 2009), we speculate that if herbivores target enriched macroalgae, this mechanism could help ameliorate increased macroalgal proliferation due to increased nutrients. Regardless, we conclude that increased nutrient supply to coral reefs likely plays an important role in shaping seaweed palatability as well as herbivore feeding patterns.

\section{LITERATURE CITED}

Bellwood DR, Hughes TP, Hoey AS (2006) Sleeping functional group drives coral-reef recovery. Curr Biol 16: 2434-2439

> Boettcher AA, Targett NM (1993) Role of polyphenolic molecular size in reduction of assimilation efficiency in Xiphister mucosus. Ecology 74:891-903

Bonaldo RM, Bellwood DR (2008) Size-dependent variation in the functional role of the parrotfish Scarus rivulatus on the Great Barrier Reef, Australia. Mar Ecol Prog Ser 360: 237-244

Boyer KE, Fong P, Armitage AR, Cohen RA (2004) Elevated nutrient content of tropical macroalgae increases rates of herbivory in coral, seagrass, and mangrove habitats. Coral Reefs 23:530-538

Burkepile DE, Hay ME (2008) Herbivore species richness and feeding complementarity affect community structure and function on a coral reef. Proc Natl Acad Sci USA 105: 16201-16206 
Burkepile DE, Hay ME (2009) Nutrient versus herbivore control of macroalgal community development and coral growth on a Caribbean reef. Mar Ecol Prog Ser 389: 71-84

> Cetrulo GL, Hay ME (2000) Activated chemical defenses in tropical versus temperate seaweeds. Mar Ecol Prog Ser 207:243-253

Coley PD, Bryant JP, Chapin FS III (1985) Resource availability and plant antiherbivore defense. Science 230: 895-899

Cronin G, Hay ME (1996) Within-plant variation in seaweed palatability and chemical defenses: optimal defense theory versus the growth-differentiation balance hypothesis. Oecologia 105:361-368

> Cruz-Rivera E, Hay ME (2003) Prey nutritional quality interacts with chemical defenses to affect consumer feeding and fitness. Ecol Monogr 73:483-506

Duffy JE, Hay ME (1990) Seaweed adaptations to herbivory. Bioscience 40:368-375

- Erickson AA, Paul VJ, Van Alstyne KL, Kwiatkowski LM (2006) Palatability of macroalgae that use different types of chemical defenses. J Chem Ecol 32:1883-1895

Fong P, Paul VJ (2011) Coral reef algae. In: Dubinsky Z, Stambler N (eds) Coral reefs: an ecosystem in transition. Springer, New York, NY, p 241-272

Fong P, Smith TB, Wartian MJ (2006) Epiphytic cyanobacteria maintain shifts to macroalgal dominance on coral reefs following ENSO disturbance. Ecology 87: 1162-1168

Gruner DS, Smith JE, Seabloom EW, Sandin SA and others (2008) A cross-system synthesis of consumer and nutrient resource control on producer biomass. Ecol Lett 11: $740-755$

Hillebrand H, Gruner DS, Borer ET, Bracken MES and others (2007) Consumer versus resource control of producer diversity depends on ecosystem type and producer community structure. Proc Natl Acad Sci USA 104: 10904-10909

Hoey AS, Bellwood DR (2010) Cross-shelf variation in browsing intensity on the Great Barrier Reef. Coral Reefs 29:499-508

Hughes TP (1994) Catastrophes, phase-shifts, and largescale degradation of a Caribbean coral reef. Science 265: 1547-1551

Hughes TP, Keller BD, Jackson JBC, Boyle MJ (1985) Mass mortality of the echinoid Diadema antillarum phillippi in Jamaica. Bull Mar Sci 36:377-384

> Hughes TP, Rodrigues MJ, Bellwood DR, Ceccarelli D and others (2007) Phase shifts, herbivory, and the resilience of coral reefs to climate change. Curr Biol 17:360-365

> Lefevre CD, Bellwood DR (2011) Temporal variation in coral reef ecosystem processes: herbivory of macroalgae by fish. Mar Ecol Prog Ser 422:239-251

Lewis SM (1985) Herbivory on coral reefs: algal susceptibility to herbivorous fishes. Oecologia 65:370-375

Littler MM, Taylor PR, Littler DS (1983) Algal resistance to herbivory on a Caribbean barrier reef. Coral Reefs 2: $111-118$

Editorial responsibility: Morten Pedersen, Roskilde, Denmark
Lokrantz J, Nyström M, Thyresson M, Johansson C (2008) The non-linear relationship between body size and function in parrotfishes. Coral Reefs 27:967-974

> Lowell RB, Markham JH, Mann KH (1991) Herbivore-like damage induces increased strength and toughness in a seaweed. Proc Biol Sci 243:31-38

> Mantyka CS, Bellwood DR (2007a) Direct evaluation of macroalgal removal by herbivorous coral reef fishes. Coral Reefs 26:435-442

> Mantyka CS, Bellwood DR (2007b) Macroalgal grazing selectivity among herbivorous coral reef fishes. Mar Ecol Prog Ser 352:177-185

> Meyer KD, Paul VJ, Sanger HR, Nelson SG (1994) Effects of seaweed extracts and secondary metabolites on feeding by the herbivorous surgeonfish Naso lituratus. Coral Reefs 13:105-112

> Paul VJ, Fenical W (1986) Chemical defense in tropical green algae, order Caulerpales. Mar Ecol Prog Ser 34: $157-169$

Rasher DB, Hay ME (2010) Chemically rich seaweeds poison corals when not controlled by herbivores. Proc Natl Acad Sci USA 107:9683-9688

Sotka EE, Hay ME (2009) Effects of herbivores, nutrient enrichment, and their interactions on macroalgal proliferation and coral growth. Coral Reefs 28:555-568

Stachowicz JJ, Hay ME (1996) Facultative mutualism between an herbivorous crab and a coralline alga: advantages of eating noxious seaweeds. Oecologia 105:377-387

Stiger V, Deslandes E, Payri CE (2004) Phenolic contents of two brown algae, Turbinaria turbinata and Sargassum mangarevense on Tahiti (French Polynesia): interspecific, ontogenic and spatio-temporal variations. Bot Mar 47:402-409

Taylor PR, Littler MM, Littler DS (1986) Escapes from herbivory in relation to the structure of mangrove island macroalgal communities. Oecologia 69:481-490

> Thabard M, Gros O, Hellio C, Marechal JP (2011) Sargassum polyceratium (Phaeophyceae, Fucaceae) surface molecule activity towards fouling organisms and embryonic development of benthic species. Bot Mar 54: $147-157$

> Van Alstyne KL, Houser LT (2003) Dimethylsulfide release during macroinvertebrate grazing and its role as an activated chemical defense. Mar Ecol Prog Ser 250:175-181

> Van Alstyne KL, Pelletreau KN, Kirby A (2009) Nutritional preferences override chemical defenses in determining food choice by a generalist herbivore, Littorina sitkana. J Exp Mar Biol Ecol 379:85-91

Vest SE, Dawes CJ, Romeo JT (1983) Distribution of caulerpin and caulerpicin in eight species of the green alga Caulerpa (Caulerpales). Bot Mar 26:313-316

Wiesemeier T, Hay M, Pohnert G (2007) The potential role of wound-activated volatile release in the chemical defence of the brown alga Dictyota dichotoma: blend recognition by marine herbivores. Aquat Sci 69:403-412

> Young MAL, Bellwood DR (2011) Diel patterns in sea urchin activity and predation on sea urchins on the Great Barrier Reef. Coral Reefs 30:729-736

Submitted: March 7, 2012; Accepted: July 17, 2012

Proofs received from author(s): September 15, 2012 